\title{
Construindo Juntos: a Importância do Trabalho Interdisciplinar Numa Abordagem Humanizada.
}

\author{
Silva, Ana Rita Flores Ribeiro da; Anjos, Paula Santana dos; Matsubara, Fernanda Kanada \\ Universidade Federal de São Paulo — anaritafrsilva@gmail.com
}

Introdução: o modulo de Trabalho em Saúde da Universidade Federal de São Paulo - UNIFESP, nos mostra que equipes multidisciplinares trabalham de forma mais ampla na atenção ao paciente, não tratando-o apenas como uma doença e sim verificando suas reais necessidades, mostrando ao paciente que ele é importante e que realmente estamos ouvindo o que ele diz. e com isso o modulo nos mostra que o serviço de saúde pode ser diferenciado. Objetivos: Apresentar como se deu o processo de ensino-aprendizagem da interdisciplinaridade no caso de uma esposa cuidadora pertencente a uma Unidade Básica de Saúde (UBS) na cidade de Santos. Método: Dona A. foi encaminhada para o atendimento de Trabalho em Saúde, em 2012, pela equipe da UBS do Embaré, pois começou a apresentar problemas de diabetes. ao mesmo tempo, surgiu a demanda de seu marido, que desenvolveu Mal de Alzheimer muito rapidamente, desestruturando a rotina do casal que sempre foi muito ativa. com o passar do tempo ele ficou completamente dependente e os filhos acabaram se afastamento por não conseguirem ver o pai no estado em que se encontrava, assim sobrou toda a demanda de cuidados e responsabilidade para a esposa. o projeto terapêutico singular deste último grupo de alunos, que seguiu o caso no período de setembro de 2013 a janeiro de 2014 pensou em favorecer a aproximação entre dona A. e seus filhos, de propor momentos de prazer, relaxamento e sensibilizar Dona A. para a necessidade de autovalorização. Neste processo Dona A. quis ensinar a equipe a tricotar, a jogar cartas e aprendeu algumas atividades como a construir um mural de fotos familiares, com este foi possível retomar alguns aspectos e momentos marcantes de sua história, foi possível ela coordenar as fases da atividade, e com autonomia conseguia escolher o que queria e o que não queria que fosse feito, principalmente quanto as cores e as fotos escolhidas por ela, a ação em equipe favoreceu para uma rememoração da família reunida. a todo o momento a cuidadora demonstrou prazer em poder ensinar o que gosta de fazer e vontade de aprender coisas novas. Resultados: Desde a primeira visita, dona A. recebeu muito bem a equipe e de forma carinhosa, entretanto, foi no decorrer das visitas que se sucederam que os laços de confiança e o vinculo entre nós foi se formando. Era visível sua alegria ao poder nos receber e fazer alguma atividade proposta, ou que pensávamos em conjunto e, essas ocasiões, se convertiam em histórias de sua vida. Depois de algumas visitas, dona A. começou a nos oferecer lanche da tarde, como forma de demonstrar o vinculo criado, nesses momentos, sentávamos na cozinha e passávamos a tarde inteira conversando. Conclusões: Pode-se perceber a importância da interdisciplinaridade, pois essa forma humanizada de atuar nos abriu as possibilidades de intervenção junto ao paciente. Perceber a forma como o vínculo foi criado nos faz acreditar cada vez mais nessa proposta de atuação.

Silva, Ana Rita Flores Ribeiro da; Anjos, Paula Santana dos; Matsubara, Fernanda Kanada. Construindo Juntos: a Importância do Trabalho Interdisciplinar Numa Abordagem Humanizada.. In: Anais do Congresso Internacional de Humanidades \& Humanização em Saúde [= Blucher Medical Proceedings, num.2, vol.1]. São Paulo: Editora Blucher, 2014. ISSN 2357-7282

DOI 10.5151/medpro-cihhs-10635 